\title{
KOMUNIKASI VISUAL DI ERA DIGITAL MELALUI PELATIHAN FOTOGRAFI
}

\author{
Wulan Purnama Sari ${ }^{1}$ dan Lydia Irena ${ }^{2}$ \\ ${ }^{1}$ Fakultas Ilmu Komunikasi, Universitas Tarumanagara, Jakarta \\ Email: wulanp@fikom.untar.ac.id \\ ${ }^{2}$ Fakultas Ilmu Komunikasi, Universitas Tarumanagara, Jakarta \\ Email: lydiairena@gmail.com
}

\begin{abstract}
The existence of educational institutions plays a very large role in educating human resources in Indonesia. Because in essence education has two main objectives, namely to help educate humans and make intelligent humans become good. Not only intellectually intelligent but also have a strong character, especially to face the times and globalization. Therefore the role of educational institutions must also pay attention to the development of students in the scope of soft skills by equipping them with practical skills. Photography is an important part of visual communication which is now an integral part of people's lives. Coupled with the trend of social media, human life is centered in it. So that this PKM activity aims to be a form of education for students regarding the function of photography in today's digital era. The method used in PKM activities is to conduct training for partners with student and female participants. PKM activities are carried out online using the Zoom application. The results of PKM activities indicate an increase in participants' understanding of photography, which can be seen through the pre and post PKM activity questionnaires. In addition, participants also have an interest in photography in the scope of social media, including photography techniques and recommendations for editing applications using smartphones. Suggestions from the team regarding this activity are to carry out further activities that focus on photography using smartphones for upload needs on social media.
\end{abstract}

Keywords: digital age, photography, visual communication.

\begin{abstract}
ABSTRAK
Keberadaan lembaga pendidikan sangat besar peranannya dalam mencerdaskan sumber daya manusia di Indonesia. Sebab pada hakikatnya pendidikan memiliki dua tujuan utama yaitu membantu mencerdaskan manusia dan menjadikan manusia cerdas tersebut menjadi baik. Tidak hanya cerdas secara intelektual tetapi juga memiliki karakter yang kuat, terutama untuk menghadapi perkembangan zaman dan globalisasi. Oleh karenanya peran lembaga pendidikan juga harus memperhatikan pengembangan peserta didik dalam ruang lingkup soft skill dengan membekali mereka keterampilan yang bersifat praktis. Fotografi menjadi bagian penting dalam komunikasi visual yang sekarang ini menjadi salah satu bagian integral dalam kehidupan masyarakat. Ditambah juga dengan adanya tren media sosial yang menjadikan kehidupan manusia berpusat di dalamnya. Sehingga kegiatan PKM ini bertujuan untuk menjadi bentuk edukasi bagi para siswa terkait fungsi fotografi di era digital saat ini. Metode yang digunakan dalam kegiatan PKM adalah dengan melakukan pelatihan kepada pihak mitra dengan peserta siswa dan siswi. Kegiatan PKM dilaksanakan secara daring dengan menggunakan aplikasi Zoom. Hasil kegiatan PKM menunjukkan adanya peningkatan pemahaman peserta mengenai fotografi, yang dapat dilihat melalui kuesioner pra dan paska kegiatan PKM. Selain itu, peserta juga memiliki ketertarikan terhadap fotografi dalam lingkup media sosial, termasuk didalamnya teknik fotografi dan juga rekomendasi aplikasi editing dengan menggunakan smartphones. Saran dari tim terkait kegiatan ini adalah dilaksanakannya kegiatan lanjutan yang berfokus pada fotografi dengan menggunakan smartphones untuk kebutuhan unggah di media sosial.
\end{abstract}

Kata Kunci: era digital, fotografi, komunikasi visual.

\section{PENDAHULUAN}

Pendidikan sangat berperan besar dalam perkembangan suatu bangsa terutama dalam hal pembentukan karakter. Pendidikan menghasilkan sebuah pembangunan yang bertata nilai, yang berorientasi pada pengembangan manusia (human oriented development), dengan adanya pendidikan, karakter manusia sebagai individu dan bagian dari masyarakat dapat disesuaikan dengan tuntutan ideal yang dimiliki suatu bangsa. (Sauri, 2009) 
Pendidikan pada hakikatnya memiliki dua tujuan utama, yaitu membantu mencerdaskan manusia, dan menjadikan manusia cerdas tersebut menjadi baik (Sudrajat, 2011). Atas dasar hal itu, dunia pendidikan memiliki nilai yang sangat strategis tidak hanya dalam hal transmisi dan transformasi ilmu pengetahuan, bahkan sangat strategi dalam pengembangan suatu bangsa, termasuk Bangsa Indonesia. Oleh karenanya keberadaan dari lembaga pendidikan sangat besar peranannya dalam mencerdaskan sumber daya manusia di Indonesia. Pengembangan lembaga pendidikan harus menjadi perhatian dan prioritas bagi pemerintah, baik pemerintah daerah maupun pemerintah pusat.

Pendidikan memiliki peran untuk pengembangan individu, baik secara intelektual, maupun secara karakter. Peranan ini seharusnya dijalankan sebagai bagian dari mencerdaskan bangsa, mendidik generasi penerus bangsa, yang tidak hanya cerdas secara intelektual tetapi juga memiliki karakter yang kuat, terutama untuk menghadapi perkembangan zaman dan globalisasi (Saleh, 2017). Oleh karenanya peran lembaga pendidikan juga harus memperhatikan pengembangan peserta didik dalam ruang lingkup soft skill, pembentukan karakter, membekali para peserta didik tidak hanya dengan ilmu pengetahuan tetapi juga dengan keterampilan lain yang bersifat praktis dan memperhatikan prinsip moralitas.

Atas dasar tersebut, peran lembaga pendidikan sebagai penyelenggara pendidikan sangat penting untuk keberadaan dan kemajuan suatu bangsa. Saleh (2017) menuliskan lembaga pendidik dapat dibagi ke dalam dua bentuk, yaitu lembaga pendidikan formal dan lembaga pendidikan non formal. Lembaga pendidikan formal merupakan lembaga pendidikan yang memiliki struktur dan jenjang, serta mengikuti aturan dari pemerintah dalam penyelenggaraannya. Sedangkan lembaga pendidikan non formal, merupakan lembaga pendidikan penunjang atau pelengkap dari lembaga pendidikan formal. Sekolah dan perguruan tinggi merupakan contoh dari lembaga pendidikan formal, sedangkan lembaga kursus dan sanggar merupakan contoh dari lembaga pendidikan non formal.

Sekolah menjadi lembaga pendidikan formal dan yang paling awal melakukan kontak dengan individu memiliki peranan yang penting dalam perkembangan seorang individu. Pendidikan di sekolah menjadi penting dan seharusnya tidak hanya berfokus pada pengembangan akademis dan intelektual dari individu, tetapi juga harus dikembangkan ke arah pendidikan karakter dilengkapi dengan pembelajaran praktis yang memberikan keahlian tambahan bagi individu sebagai peserta didik. Hal ini diperlukan untuk mempersiapkan peserta didik, generasi penerus bangsa untuk menghadapi tuntutan globalisasi di era digital. (Saleh, 2017; Sauri, 2009; Setiawan, 2013; Sudrajat, 2011)

Atas dasar tersebut, sekolah sebagai lembaga pendidikan formal juga memerlukan melakukan pengembangan bagi peserta didik dalam hal praktis. Sistem pendidikan di Indonesia umumnya mengedepankan sistem kurikulum yang berfokus pada pembelajaran secara intrakulikuler, pembelajaran di dalam kelas. Sementara pengembangan pembelajaran melalui kegiatan ekstrakulikuler juga diperlukan untuk pengembangan kepribadian, pengetahuan, keterkaitan antara materi di kelas dengan praktek nyata. (Lestari \& Sukanti, 2016)

Kegiatan ekstrakulikuler merupakan kegiatan diluar jam sekolah, dengan tujuan agar siswa dapat memperluas dan mengembangkan pengetahuan, kepribadian, minat dan bakat, dan kemampuan lainnya di luar bidang akademik. Umumnya kegiatan ekstrakurikuler berbentuk kegiatan di bidang seni, olahraga, pengembangan kepribadian dan kegiatan lain yang bertujuan positif. Kegiatan 
ekstrakulikuler dilaksanakan berdasarkan inisiatif dari pihak sekolah, walaupun pengembangannya telah memiliki landasan hukum yang kuat yang tertera dalam surat keputusan mentri pada tahun 2002 kemarin. Kegiatan ekstrakurikuler ini juga bermanfaat sebagai perantara antara pembelajaran pengetahuan yang diperoleh dalam kelas dengan pengembangan ketrampilan dan sikap dalam prakteknya. (Dahliyana, 2017; Lestari \& Sukanti, 2016)

Salah satu kegiatan ekstrakurikuler yang dapat dikembangkan di sekolah adalah kegiatan fotografi. Fotografi secara sederhana dapat diartikan sebagai proses atau metode untuk menghasilkan gambar dari suatu objek, yang biasanya menggunakan alat yang disebut dengan kamera. Dunia fotografi ikut berkembang seiring dengan perkembangan zaman dan teknologi yang semakin canggih, termasuk di Indonesia yang dapat dilihat dari semakin banyaknya perlombaan fotografi yang diselenggarakan. Terlebih lagi sejak adanya smartphones yang sekarang ini dilengkapi dengan fitur kamera, dan maraknya penggunaan media sosial seperti Instagram. Oleh karenanya, pembelajaran tentang fotografi ini patut menjadi fokus sejak pada masa sekolah.

Peluang kerja di bidang fotografi pun masih terbuka luas, misalnya sebagai fotografer produk, makanan, model, dll. Banyak bidang yang membutuhkan fotografer, seperti jurnalistik, fashion, bahkan tidak jarang para selebgram, bloggers dan youtuber saat ini yang memiliki fotografer pribadi untuk mendukung pekerjaan mereka. Pembejaran fotografi bahkan dapat dimulai hanya dengan menggunakan smartphones. Sekarang bahkan industri perfilman Hollywood telah mulai memproduksi film hanya dengan menggunakan kamera dari smartphone, seperti film Tangerine, Olive, dan The Commuter (Dewi, 2016).

Peluang di bidang fotografi juga dimanfaatkan sekolah untuk membuat kegiatan ekstrakurikuler di bidang tersebut, salah satunya adalah sekolah SMAN 100 Jakarta yang berlokasi di Cipinang. SMAN 100 telah memiliki ekstrakurikuler fotografi sebagai kegiatan penunjang bagi para siswanya, ekstrakurikuler fotografi tersebut juga telah pernah mengikuti perlombaan dan memenangkan salah satu kategori. Kendala yang dialami adalah terkait dengan pengelolaan dari kegiatan ekstrakurikuler tersebut. Pihak sekolah menemui kesulitan untuk mencari pembimbing atau mentor untuk membantu para siswa, sejauh ini yang menjadi pembimbing kegiatan ekstrakurikuler fotografi adalah alumni yang berasa dari sekolah tersebut. Hal ini disebabkan karena adanya keterbatasan dana yang dimiliki oleh pihak sekolah, sehingga tidak memungkinkan bagi pihak sekolah untuk mencari pembimbing profesional. Keterbatasan dana ini juga mengakibatkan pihak sekolah kesulitan dalam hal menyediakan kamera dan alat penunjang fotografi lainnya. Kondisi ini ditambah dengan tidak adanya guru pembimbing khusus yang menguasi bidang fotografi.

Melihat antusiasme para siswa anggota ekstrakurikuler fotografi, pihak sekolah sangat mendukung untuk diadakannya kegiatan Pengabdian Kepada Masyarakat (PKM) untuk membantu para siswa. Kegiatan PKM ini direncanakan diadakan dalam bentuk pelatihan fotografi, para peserta nantinya akan belajar secara langsung mengenai teknik-teknik fotografi serta perkembangan tren saat ini. Kegiatan PKM ini dibutuhkan untuk membantu pengembangan potensi dari para siswa anggota kegiatan fotografi, untuk mengasah kemampuan dan pengetahuan yang dimiliki terkait fotografi. Kegiatan PKM ini juga menjadi bentuk edukasi bagi para siswa terkait fungsi fotografi di era digital saat ini.

Fotografi menjadi bagian penting dalam komunikasi visual, proses penting dalam komunikasi visual adalah penyampaian informasi melalui visual atau gambar. Komunikasi visual sekarang ini menjadi salah satu bagian penting dalam kehidupan masyarakat, ditambah dengan adanya tren media sosial. Media sosial menjadikan kehidupan manusia berpusat di dalamnya, sebagai contoh 
saat ini ada kecenderungan untuk mengunggah setiap aktivitas ke dalam media sosial, mulai dari makanan, travelling, fashion, dsb.

Berdasarkan analisis situasi yang telah diuraikan diatas, maka dapat disimpulkan permasalahan prioritas yang dihadapi mitra adalah kesulitan untuk mencari pembimbing yang dapat membantu siswa anggota kegiatan ekstrakurikuler fotografi untuk mengembangkan potensi yang dimilikinya. Sementara, sebagai lembaga pendidikan, mitra dalam hal ini memiliki kewajiban untuk membantu para siswa dalam mengembangkan kemampuannya tidak hanya dalam hak akademis tetapi juga non akademis, terlebih di tengah tuntutan zaman sekarang ini.

Pengusul melihat permasalahan ini dalam kaitannya dengan pentingnya edukasi bagi para siswa terkait dengan komunikasi visual dan tren masyarakat saat ini yang tidak dapat dipisahkan dari media sosial dan fotografi. Terlebih lagi peluang di bidang fotografi masih terbuka dengan luas, sehingga dapat membantu para siswa kedepannya bila berkeinganan untuk menggeluti profesi fotografer. Program PKM ini disusun untuk meningkatkan kesadaran, pengetahuan, dan kemampuan para siswa dalam hal komunikasi visual, khususnya fotografi.

Solusi untuk menjawab permasalahan mitra adalah dengan melaksanakan kegiatan PKM dalam bentuk pelatihan fotografi sebagai bagian dari pembelajaran komunikasi visual. Pelatihan fotografi meliputi teori dan praktek tentang, yaitu: (1) Pengertian fotografi; (2) Pengenalan atas jenis-jenis fotografi; (3) segitiga exposure; (4) Teknik - teknik dasar fotografi beserta komposisinya. Terkait dengan genre fotografi sendiri dapat diklasifikasikan ke dalam beberapa jenis, yaitu: fotografi jurnalistik, fotografi still life, portrait fotografi, fotografi commercial advertising, fotografi wedding, fotografi fashion, fotografi makanan (food), fotografi fine art, fotografi landscape, fotografi wildlife, fotografi makro. (Gunawan, 2014)

Beberapa teknik fotografi yang juga akan diperkenalkan diajarkan pada saat pelatihan adalah zooming, panning, freezing, makro, siluet, bulb, komposisi dari field of view, dan sudut pengambilan gambar. Target dari kegiatan PKM ini adalah adanya peningkatan kesadaran, pengetahuan, dan kemampuan siswa dalam hal fotografi beserta dampaknya bila dilihat dari sisi komunikasi visual. Pengukuran pencapaian target ini akan dilakukan dengan menggunakan kuesioner pada saat sebelum dan setelah pelatihan.

\section{METODE PELAKSANAAN PKM}

Metode pelaksanaan ini menjelaskan cara atau metode yang digunakan dalam proses keseluruhan kegiatan PKM, mulai dari tahapan pra-kegiatan, pelaksanaan, sampai kepada paska kegiatan. Bagian ini diperuntukkan untuk menjadi panduan bagi tim PKM dalam melaksanakan kegiatan PKM, serta melakukan transfer dari solusi yang ditawarkan oleh tim kepada mitra. Bagan alir kegiatan PKM yang menjelaskan tahapan dalam metode pelaksanaan kegiatan dapat dilihat pada Gambar 1.

Kegiatan PKM ini dibagi ke dalam tiga tahap besar, yaitu sebelum kegiatan atau pra-kegiatan, pelaksanaan kegiatan, dan setelah kegiatan. Tahapan pra-kegiatan dimulai dengan melakukan audiensi dengan pihak mitra, audiensi dilakukan untuk meminta persetujuan dalam bentuk surat pernyataan, kemudian memetakan masalah yang dimiliki mitra dan menentukan solusi dari permasalahan tersebut. Hasil audiensi tersebut kemudian dituliskan dalam bentuk proposal kegiatan PKM, yang mencakup analisis masalah, solusi dan luaran, metode pelaksanaan, serta anggaran yang dibutuhkan. Setelah itu, proposal kemudian diajukan kepada pihak mitra atas dasar permintaan dari pihak mitra juga diajukan kepada LPPM Untar untuk mendapatkan dana hibah PKM. Pada tahap ini tim juga sudah mulai mempersiapkan materi dan peralatan yang dibutuhkan 
dalam kegiatan pelatihan. Pada tahap ini juga dicari kesepakatan antara tim dan mitra mengenai waktu pelaksanaan dari kegiatan PKM sekaligus bentuk partisipasi mitra dalam kegiatan PKM tersebut.

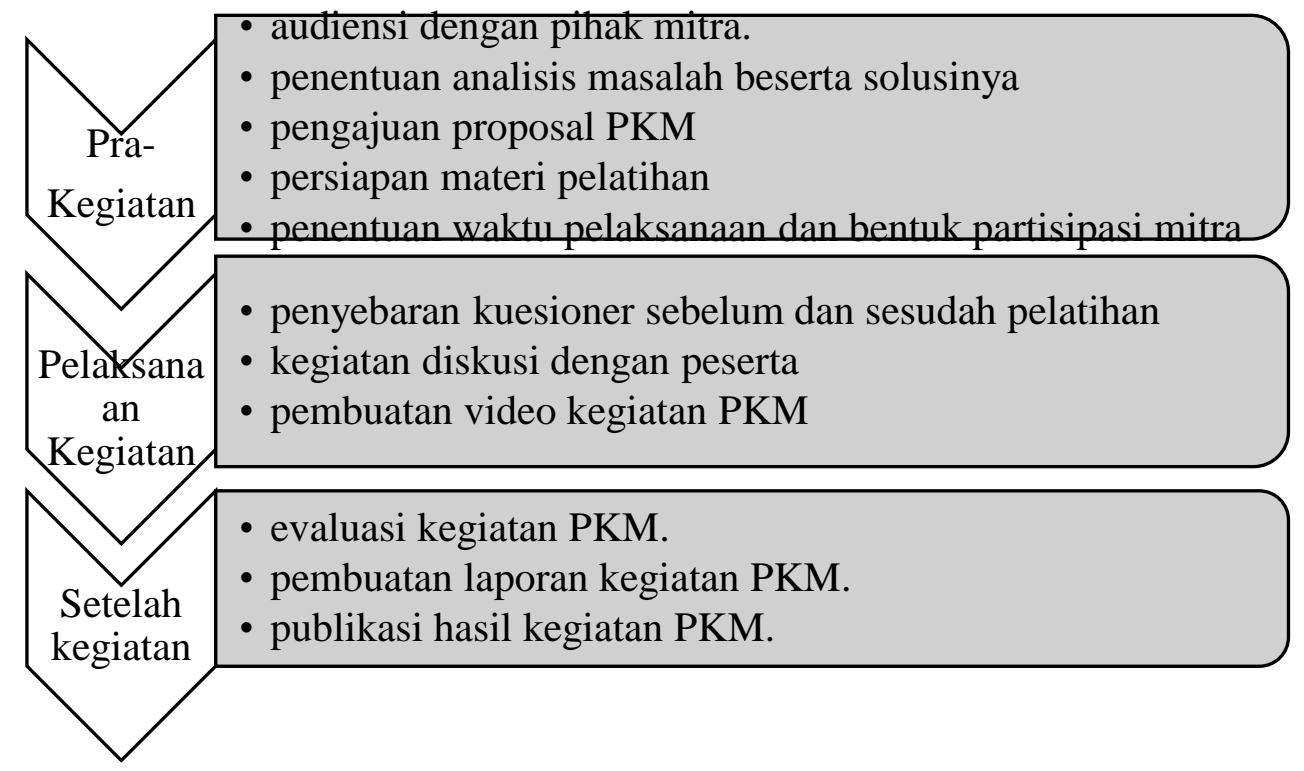

Gambar 1. Tahapan Kegiatan PKM

Tahap kedua merupakan tahap pelaksanaan. Tahap ini dimulai dengan penyebaran kuesioner sebelum dan setelah kegiatan yang bertujuan untuk mengukur efektivitas dari kegiatan PKM yang dilakukan. Kegiatan PKM ini meliputi pemberian pelatihan terkait genre, teknik, dan etika dalam dunia fotografi. Kegiatan ini juga mencakup sesi diskusi beserta praktek langsung yang akan dibantu oleh mahasiswa dari Fikom Untar. Pada saat tahap ini, seluruh kegiatan juga akan didokumentasikan dalam bentuk video yang nantinya menjadi salah satu bentuk luaran dari kegiatan PKM ini.

Tahap ketiga merupakan tahap pasca kegiatan yang mencakup evaluasi kegiatan, pembuatan laporan PKM dan publikasi dari kegiatan. Evaluasi dilakukan dengan mengacu pada alat ukur kuesioner yang disebarkan dalam tahap pelaksanaan. Setelah itu, kegiatan dan hasil evaluasi disusun dalam bentuk laporan sebagai bentuk pertanggungjawaban tim kepada mitra dan pemberi dana hibah PKM. Kegiatan terakhir dalam tahap ini melakukan publikasi dari kegiatan PKM, seperti telah dituliskan dalam bagian solusi dan luaran di bab 2, publikasi dilakukan sebagai bentuk diseminasi, publikasi dilakukan di jurnal nasional beserta pendaftaran HKI atas video kegiatan.

Sebagai bentuk kerjasama dan persetujuan dalam kegiatan ini, mitra yang dalam hal ini adalah sekolah SMAN 100 Jakarta memberikan partisipasi dalam beberapa bentuk. Pertama, pemberian surat persetujuan sebagai mitra. Kedua menyediakan waktu dan tempat untuk pelaksanaan kegiatan PKM. Pembahasan dalam metode pelaksanaan ini juga mencakup penjelasan dari kepakaran atau keahlian yang dimiliki seluruh anggota tim yang terlibat dalam kegiatan PKM.

\section{HASIL DAN PEMBAHASAN}

Kegiatan PKM pada semester ini mengalami kendala dikarenakan beberapa hal, pertama terjadi pandemi COVID-19 yang menjadikan seluruh kegiatan harus dilaksanakan secara daring. Jadwal pelaksanaan yang pada awalnya telah disepakati dengan mitra terpaksa diundur menjadi akhir Agustus ini. Kedua, persiapan yang tadinya telah dilakukan untuk kegiatan secara luring, 
kemudian harus diubah semua menjadi daring. Tim PKM kembali harus menyesuaikan materi serta sarana yang dibutuhkan untuk menunjang kegiatan secara daring.

Setelah didiskusikan, PKM dilakukan secara daring pada Sabtu, 5 September 2020, pukul 10.00 melalui perangkat Zoom. Berbagai persiapan terkait susunan acara, materi fotografi, dan lain sebagainya disiapkan dengan sedemikian rupa oleh tim dan beberapa asisten mahasiswa yang turut membantu. Pada hari berlangsungnya acara, terdapat 30 peserta yang merupakan siswa/I SMA Negeri 100 Jakarta yang mengikuti kegiatan ini. Didampingi dengan guru pembimbing ekstrakurikuler fotografi, sejumlah siswa/i dengan antusias mengajukan banyak pertanyaan yang mereka miliki seputar dunia fotografi.

Sebelum kegiatan PKM dimulai, peserta PKM diminta untuk mengisi kuesioner. Kuesioner ini digunakan sebagai alat ukur untuk menilai efektivitas dari kegiatan PKM, sekaligus bentuk monitoring dan evaluasi yang dilakukan oleh tim. Acara dimulai dengan pembukaan dari pihak mitra yang diwakilkan oleh kepala sekolah SMAN 100, Bapak Drs. Sunaryanto, M.Pd, pihak sekolah merasa kegiatan PKM merupakan sarana pembelajaran baru bagi para siswa/I di masa pandemi seperti sekarang ini dan berharap kegiatan seperti ini dapat menjadi agenda rutin sekaligus bentuk kolaborasi antara sekolah dengan universitas. Setelah pembukaan, acara PKM dilanjutkan dengan pembukaan dari pihak tim PKM Fikom Untar, yang langsung dilanjutkan dengan pemaparan materi oleh mahasiswa Fikom Untar. Peserta PKM Fotografi dapat dilihat pada Gambar 2.

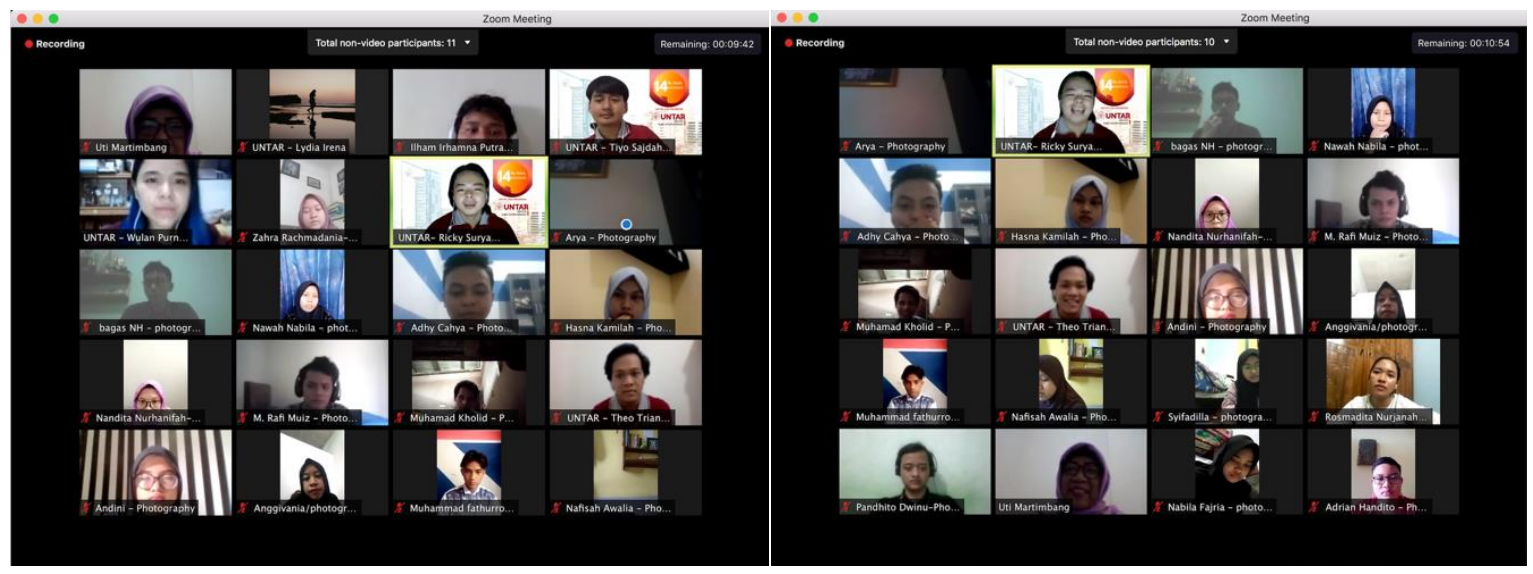

Gambar 2. Peserta PKM Fotografi

Pembagian materi tentang fotografi dibantu oleh asisten mahasiswa yang juga merupakan anggota dari Unit Kegiatan Mahasiswa Fakultas yaitu IFocus. Pengetahuan yang selama ini mereka telah dapatkan turut dibagikan kepada siswa/i peserta. Materi tersebut di antaranya adalah tentang pengertian sebenarnya tentang fotografi, berbagai jenis fotografi, segitiga exposure dalam fotografi, teknik dasar fotografi, dan cara mengatur komposisi dalam fotografi. Beberapa teknik fotografi yang juga akan diperkenalkan diajarkan pada saat pelatihan adalah zooming, panning, freezing, makro, siluet, bulb, komposisi dari field of view, dan sudut pengambilan gambar.

Setelah pemberian materi, acara PKM dilanjutkan dengan sesi diskusi dan tanya jawab dari peserta. Pertanyaan tidak hanya materi yang diberikan tetap juga pada fotografi praktis dalam kegiatan sehari-hari, seperti foto menggunakan smartphone, rekomendasi aplikasi editing untuk smartphone, dan tips untuk fotographer pemula. Berdasarkan hasil tanya jawab diperoleh pemahaman tambahan bahwa cara terbaik untuk meningkatkan kemampuan fotografi adalah dengan terus menerus melakukan praktek, karena fotografi merupakan seni mengolah cahaya, dan perangkat yang bagus hanya merupakan pendukung. 
Pertanyaan peserta banyak berpusat pada masalah fotografi dengan menggunakan smartphone dan terkait dengan kebutuhan untuk media sosial. Hal ini menunjukkan bahwa tren media sosial menjadi daya tarik tersendiri, khususnya dikalangan generasi muda (Moriansyah, 2015; Semuel \& Setiawan, 2018; Yu, Asur, \& Huberman, 2015). Teknik atau tips sederhana yang dapat digunakan saat pengambilan foto dengan menggunakan smartphone ataupun aplikasi yang mudah untuk melakukan editing. Proses tanya jawab peserta dapat dilihat pada Gambar 3.
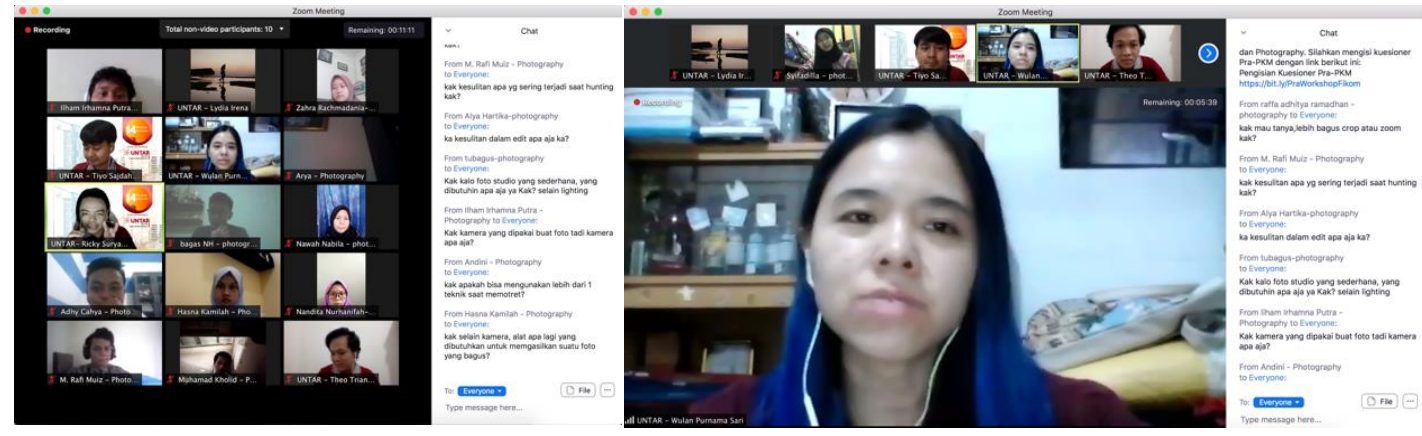

Gambar 3. Tanya Jawab Peserta

Seperti yang telah dikemukakan sebelumnya bahwa target dari kegiatan PKM ini adalah adanya peningkatan kesadaran, pengetahuan, dan kemampuan siswa dalam hal fotografi beserta dampaknya bila dilihat dari sisi komunikasi visual. Pengukuran pencapaian target ini akan dilakukan dengan menggunakan kuesioner pada saat sebelum dan setelah pelatihan. Hasil kuesioner peningkatan pemahaman peserta dapat dilihat pada Tabel 1.

Tabel 1. Peningkatan Pemahaman Peserta

\begin{tabular}{lcc}
\hline Pemahaman & Pra-Workshop & Pasca-Workshop \\
\hline Pengertian sebenarnya tentang fotografi & 3,23 & 4,62 \\
\hline Berbagai jenis fotografi & 2,58 & 4,59 \\
\hline Segitiga exposure dalam fotografi & 2,04 & 4,34 \\
\hline Teknik dasar fotografi & 2,88 & 4,62 \\
\hline Cara mengatur komposisi dalam fotografi & 2,58 & 4,28 \\
\hline
\end{tabular}

Tabel 1 menunjukkan adanya peningkatan pemahaman yang cukup signifikan dari para siswa/i peserta. Pada materi tentang pemahaman sebenarnya tentang fotografi terdapat peningkatan sebesar 1,39. Kemudian dalam perihal berbagai jenis fotografi, pemahaman siswa meningkat sebesar 2,01. Pemahaman tentang segitiga exposure dalam fotografi juga meningkat paling signifikan yaitu sebesar 2,3. Sedangkat pada materi teknik dasar fotografi meningkat sebanyak 1,74 dan perihal cara mengatur komposisi dalam fotografi bertambah sebanyak 1,7. Presentasi fotografi secara daring dapat dilihat pada Gambar 4.

Secara keseluruhan rangkaian kegiatan PKM berjalan dengan lancar dan baik, walaupun tidak dapat dihindari terdapat kendala teknis dikarenakan acara dilakukan secara daring. Misalnya kendala dalam masalah koneksi internet, dan juga karena dilangsungkan secara daring interaksi antara tim PKM dengan peserta menjadi terbatas. Pengajuan pertanyaan dari peserta hanya dapat melaluii fitur-fitur yang disediakan oleh aplikasi Zoom, seperti melalui fitur chat dan raise hand. 
Selain itu, kendala daring ini juga menyulitkan tim untuk melakukan praktek fotografi secara langsung.

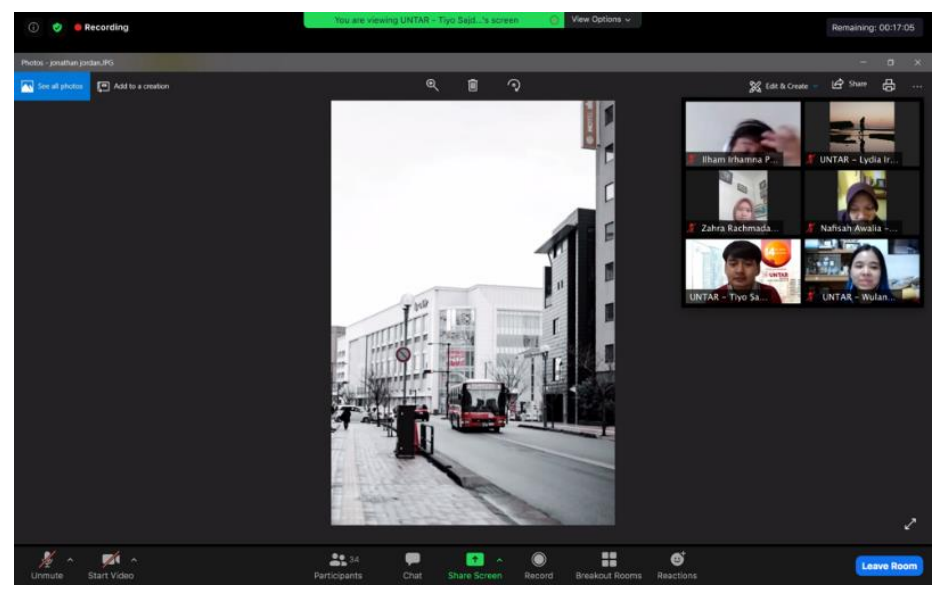

Gambar 4. Presentasi Fotografi secara Daring

\section{KESIMPULAN DAN SARAN}

Kesimpulan utama yang dapat diperoleh melalui kegiatan ini adalah kegiatan PKM merupakan sarana untuk menjalin kerjasama antar institusi pendidikan (sekolah dengan universitas), dimana kedua pihak saling diuntungkan dari adanya kegiatan PKM. Terkait kegiatan PKM ini sendiri pelaksanaannya sempat mendapatkan kendala karena adanya pandemi COVID-19 yang menjadikan kegiatan PKM diundur dan akhirnya dilakukan secara daring dengan segala kendala dan keterbatasannya. Secara keseluruhan rangkaian acara berjalan dengan lancar dan baik.

Kegiatan PKM mengenai fotografi dalam kaitannya dengan komunikasi visual berhasil meningkatkan pemahaman peserta yang dapat dilihat melalui kuesioner pra dan paska kegiatan. Selain itu, kegiatan seperti ini juga menambah pemahaman praktis peserta mengenai fotografi dalam keseharian, misalnya fotografi dengan menggunakan smartphone, baik untuk pengambilan gambar maupun untuk melakukan editing

Rekomendasi dari tim PKM terkait kegiatan PKM ini adalah masukan untuk pengembangan pelaksanaan kegiatan PKM berikutnya dengan tema fotografi. Pertama, melakukan kegiatan PKM dengan berfokus pada tren fotografi di media sosial, kegiatan PKM dapat meliputi tips sederhana dengan luaran foto untuk diunggah di media sosial. Kedua, melakukan kegiatan PKM secara luring sehingga praktek pengambilan foto dapat dilakukan secara langsung, sehingga peserta kegiatan mendapatkan pengalaman langsung.

\section{Ucapan Terima Kasih (Acknowledgement)}

Ucapan terima kasih penulis sampaikan kepada pihak mitra SMAN 100 Jakarta yang telah bersedia menjadi mitra dan bekerjasama dalam pelaksanaan kegiatan PKM ini. Berikutnya ucapan terima kasih juga ditujukan kepada para siswa/I SMAN 100 Jakarta yang telah berpartisipasi dalam kegiatan PKM ini. Terkahir, ucapan terima kasih diberikan kepada LPPM Untar selaku pemberi dana hibah dan juga rekan-rekan mahasiswa Fikom Untar.

\section{REFERENSI}

Dahliyana, A. (2017). Penguatan Pendidikan Karakter Melalui Kegiatan Ekstrakurikuler Di 
Sekolah. Sosio Religi: Jurnal Kajian Pendidikan Umum, 15(1), 54-64. Retrieved from https://ejournal.upi.edu/index.php/SosioReligi/article/view/5628/3821

Dewi, A. R. (2016). Tak diduga, 5 film keren ini ternyata dibikin dengan kamera handp. Retrieved February 14, 2020, from https://www.brilio.net/wow/tak-diduga-5-film-keren-initernyata-dibikin-dengan-kamera-handphone-160205i.html\#

Gunawan, A. P. (2014). Genre Fotografi yang Diminati oleh Fotografer di Indonesia. Humaniora, 5(2), 1234-1245. https://doi.org/10.21512/humaniora.v5i2.3266

Lestari, P., \& Sukanti. (2016). Membangun Karakter Siswa Melalui Kegiatan Intrakurikuler, Ekstrakurikuler, dan Hidden Curriculum di SD Budi Mulia Dua Pandeansari Yogyakarta. JURNAL PENELITIAN, 10(1), 71-96. Retrieved from http://journal.iainkudus.ac.id/index.php/jurnalPenelitian/article/view/1367/1245

Moriansyah, L. (2015). Pemasaran Melalui Media Sosial: Antecedents Dan Consequences. Jurnal Penelitian Komunikasi Dan Opini Publik, 19(3), 187-196. https://doi.org/http://dx.doi.org/10.33299/jpkop.19.3.346

Saleh, S. (2017). Peran Lembaga Pendidikan Dalam Membentuk Karakter Bangsa. In Prosiding Seminar Nasional Himpunan Sarjana Ilmu-ilmu Sosial (pp. 101-112). Makassar: UNM \& Himpunan Sarjana Ilmu-ilmu Sosial. Retrieved from https://ojs.unm.ac.id/PSNHSIS/article/view/2735

Sauri, S. (2009). Membangun Karakter Bangsa Melalui Pendidikan Profesionalisme Guru Berbasis Pendidikan Nilai. Retrieved from http://file.upi.edu/Direktori/FPBS/JUR._PEND._BAHASA_ARAB/195604201983011SOFYAN_SAURI/SEMINAR_2009/makalah_karakter_guru.pdf

Semuel, H., \& Setiawan, K. Y. (2018). Promosi Melalui Sosial Media, Brand Awareness, Purchase Intention Pada Produk Sepatu Olahraga. Jurnal Manajemen Pemasaran, 12(1), 47-52. https://doi.org/10.9744/PEMASARAN.12.1.47-52

Setiawan, D. (2013). PERAN PENDIDIKAN KARAKTER DALAM MENGEMBANGKAN KECERDASAN MORAL. Jurnal Pendidikan Karakter, $O(1)$. https://doi.org/10.21831/JPK.V0I1.1287

Sudrajat, A. (2011). Mengapa Pendidikan Karakter? Jurnal Pendidikan Karakter, 1(1). https://doi.org/10.21831/JPK.V1I1.1316

Yu, L. L., Asur, S., \& Huberman, B. A. (2015). Trend Dynamics and Attention in Chinese Social Media. American Behavioral Scientist, 59(9), 1142-1156. https://doi.org/10.1177/0002764215580619 